\title{
Effect of bacterization with Pseudomonas extremorientalis PhS1 on photosynthesis processes in wheat plants (Triticum aestivum L.) under phytopathogenic load \\ Zyubanova T.I. ${ }^{1,2}$, Minaeva O.M..$^{1,2}$, Tereshchenko N.N. ${ }^{1,2}$ \\ ${ }^{1}$ Tomsk State University, Tomsk, Russia; ${ }^{2}$ Siberian Research Institute of Agriculture and Peat, Tomsk, Russia E-mail: zyubanovat.i@gmail.com
}

Key message. We found that bacterization of wheat with Pseudomonas extremorientalis increases the efficiency of open photosystem II reaction centers and reduces the photosynthesis losses dissipated as heat in the presence of a phytopathogen. Keywords: bacterization, chlorophyll fluorescence, plant resistance At all stages, photosynthesis is subject to the deforming effect of various stresses, including biotic ones, such as plant damage by phytopathogens. At present, it has been established that one of the most objective criteria for the activity of the photosynthetic apparatus of plants is chlorophyll fluorescence. Physiologically significant data are obtained on the basis of the analysis of such kinetic parameters as background and maximum fluorescence, maximum quantum yield of photosystem II, etc. These parameters both reflect the physiological state of plants and can be used to assess plant resistance, to conduct environmental monitoring and to predict crop yields.

The aim of this research was to identify the effect of Pseudomonas extremorientalis PhS1 bacteria on the activity of photosynthesis processes in wheat plants infected with Bipolaris sorokiniana.

The objects of the research were 12-day wheat plants (Triticum aestivum L., Iren cultivar) inoculated with a liquid 24-hour bacterial culture P. extremorientalis PhS1. A six-day culture of Bipolaris sorokiniana on a solid medium was used to infect plants. Plants were grown in a climate chamber (Growth Chamber GLK-300, Korea) in plastic containers with peat substrate. The light intensity was $200 \mu \mathrm{mol}$ quanta/ $\left(\mathrm{m}^{2} \mathrm{~s}\right)$ of PAR with a 16 -hour photoperiod at $20-22^{\circ} \mathrm{C}$ (day) and $15-16^{\circ} \mathrm{C}$ (night) and with $80 \%$ humidity. Chlorophyll $a$ fluorescence was measured after 30 minutes of dark adaptation of plants using a fluorimeter (JUNIOR-PAM, Walz, Germany).

It was identified that neither bacterization nor the presence of the pathogen have a significant effect on the indicators of the maximum efficiency of photosystem II and photochemical fluorescence quenching coefficients. Bacterization contributed to an increase in the speed of electronic transport by $7 \%$ in the absence of the phytopathogen and in its presence by $6 \%$ (p <0.05) compared to nonbacterized plants under the same conditions, which may indicate a decrease in stress. In tests, a decrease in non-photochemical quenching during bacterization and in the presence of the phytopathogen was found to be $7-17 \%$ $(\mathrm{p}<0.05)$, which indicates a decrease in energy losses and heat dissipation.

\section{Влияние бактерий Pseudomonas extremorientalis PhS1 на процессы фотосинтеза растений пшеницы (Triticum aestivum L.) в условиях фитопатогенной нагрузки Зюбанова Т.И. ${ }^{1,2}$, Минаева O.M. ${ }^{1,2}$, Терещенко H.H. ${ }^{1,2}$}

${ }^{1}$ Национальный исследовательский Томский государственный университет, Томск, Россия; ${ }^{2}$ СибНИИСХиТ - филиал СФНЦА РАН, Томск, Россия

\begin{abstract}
Аннотация. Показано, что бактеризация пиеницы Pseudomonas extremorientalis увеличивает эффективность открытых реакционных иентров фотосистемы II и снижает потери фотосинтеза, рассеиваемые в виде тепла, в присутствии фитопатогена.
\end{abstract}

Ключевые слова: бактеризация, флуоресценция хлорофилла, резистентность растений

Фотосинтез на всех этапах подвержен деформирующему воздействию различных стрессов, включая биотические, такие как поражение растений фитопатогенами. В настоящее время установлено, что одним из наиболее объективных критериев активности фотосинтетического аппарата растений являются показатели флуоресценции хлорофилла. Физиологически значимые данные получают на основе анализа таких кинетических параметров, как фоновая и максимальная флуоресценции, максимальный квантовый выход фотосистемы II и др. Данные параметры отражают как физиологическое состояние растений, так и могут быть использованы для оценки устойчивости растений, экологического мониторинга и прогнозирования урожаев.

Цель работы: изучить влияние фосфатмобилизующих бактерий Pseudomonas extremorientalis $\mathrm{PhS} 1$ на активность процессов фотосинтеза растений пшеницы в моделируемых условиях повышенного инфекционного фона.

Объекты исследования: 12-ти дневные растения пшеницы (Triticum aestivum L., сорт Ирень) инокулированные жидкой 24 часовой культурой бактерий $P$. extremorientalis $\mathrm{PhS1}$. Для создания инфекционного фона использовали шестисуточную культуру Bipolaris sorokiniana на плотной среде. Фитопатоген вносили в виде агаровых блоков в ряды с семенами при посадке. Растения выращивали в климатокамере (Growth Chamber GLK-300, Корея) в пластиковых контейнерах с торфяным субстратом. Интенсивность освещения - 200 мкмоль квантов $/\left(\mathrm{m}^{2}\right.$ сек) ФАР с 16-часовым фотопериодом при $20-22^{\circ} \mathrm{C}$ (дневные температуры) и $15-16^{\circ} \mathrm{C}$ (ночные) и влажности $80 \%$. Флуоресценцию хлорофилла $a$ измеряли после 30 минутной темновой адаптации растений при помощи флуориметра (JUNIOR-PAM, Walz, Германия).

Установлено, что ни бактеризация, ни наличие инфекционного фона не оказывают значимого влияния на показатели максимальной эффективности фотосистемы II и коэффициенты фотохимического тушения флуоресценции. Бактеризация способствовала увеличению скорости электронного транспорта на $7 \%$ в отсутствии фитопатогена и на $6 \%$ (р $<0,05)$ на инфекционном фоне относительно небактеризованных растений в тех же условиях, что может свидетельствовать об уменьшении стресса. Обнаружено уменьшение показателей нефотохимического тушения при бактеризации и наличия фитопатогена на $7-17 \%(\mathrm{p}<0,05)$, что свидетельствует об уменьшении потерь энергии и рассеивании в виде тепла. 